Janez ŠTEBE, Tina VOVK*

\title{
GENDER INEQUALITY ON DISPLAY IN THE FLEXIBILISATION OF EMPLOYMENT DURING THE COVID-19 CRISIS IN SLOVENIA**
}

\begin{abstract}
Many risks are associated with the Covid-19 crisis and related lockdown measures in the areas of employment, the economy, and everyday life. Working parents have faced the challenge of combining their work and family obligations following the closure of schools and kindergartens. A considerable number have encountered a bigger risk of unemployment and the linked financial instability. The extensive literature analysing changes during Covid-19 suggests that women have tended to suffer more, been faced with both less stability since their employment statuses appear to be more precarious, and been disproportionally affected by the heavier burden of balancing family care and work obligations. Our own analysis of the most reliable survey data available shows corresponding changes in Slovenia, confirming that the crisis reveals certain less visible, already existing inequalities along with particular new gender inequalities, and in this respect also presents specific research design conditions for assessing otherwise hidden disparities. The results indicate the consequences for the subjective well-being of women compared to men of the more precarious employment and the stronger demand for family care.
\end{abstract}

Keywords: Covid-19, gender inequalities, employment flexibility, work from home, family care, life satisfaction

\section{Introduction}

The first Covid-19 case was confirmed in Slovenia on 4 March 2020, with an epidemic being officially declared on 12 March 2020. Many economic

* Janez Štebe, PhD, Assistant Professor, Faculty of Social Sciences, University of Ljubljana, Slovenia; Tina Vovk, MSc, Researcher, Public Opinion and Mass Communication Research Centre, Faculty of Social Sciences, University of Ljubljana, Slovenia.

** Research is supported by a grant from the ARRS HIO-OO22 (A) Network of Research Infrastructure Centres and by ARRS research project grant P5-0151.

DOI: $10.51936 /$ tip.58.specialissue.576-597 
activities were put on hold (like tourism, restaurants, personal transport) leading to temporary lay-offs, while working from home was advised for those able to afford it and according to the type of work involved (Gospodarska zbornica Slovenije, 2020; Covid-19 Tracker, 2020; ILO, 2021).

The pandemic together with the lockdown introduced to prevent the virus' spread hold wider consequences for well-being, not only by way of deteriorating health. The general economic recession at the country level and financial uncertainty at the household level have been to the detriment of well-being, as have the changes in everyday life like reduced social contact, travel, family life due to the closure of school and childcare facilities etc. In the present analysis, we concentrate on changes in the working life of individuals and explore whether the pandemic has affected men and women differently. It is expected that the crisis might be disproportionately exposing certain parts of the population, thereby revealing who is more vulnerable based on otherwise less visible, already existing inequalities, depending on one's job and how stable and rewarding it is.

We also consider how work might interfere with family life and thus its wider consequences for life satisfaction. Accordingly, we wish to assess whether the changes introduced by the external factor of the pandemic perhaps also reveal and add to inequality in the sharing of household duties and care work established prior to Covid-19. The question is relevant with respect to considering the policy impacts of Covid-19 on gender equality in employment. Working mothers' vulnerability to stress following the increased and unequally shared burden of work and family responsibilities runs counter to the goal of the Work-Life Balance Directive that introduces "flexible working arrangements for workers, and promotes equal sharing of caring responsibilities between parents" (Communication from the Commission, 2020). Carefully-designed policy recommendations concerning work flexibilisation must lead to a reduction of negative pressures on well-being and enable positive aspects to surface (Reuschke, 2019). The public's strong negative reaction to the short video prepared by the Ministry of Work (Slovenske novice, 14. 12. 2020) showing an idealised image of working from home demonstrates the approach to promoting flexible work arrangements must remain realistic by including a balanced view of both the positive and negative aspects (Eurofound, 2020).

Flexible work arrangements take many different forms, yet each category may be described as either desirable or undesirable. In particular, it is interesting to explore where already existing inequalities have come to the surface or been reinforced by the Covid-19 shock, and if new ones have arisen either temporarily or are perhaps more long-term in nature. To assess the long-lasting potential of changes and the support for them, an evaluation was performed by testing its effect on increasing/decreasing inequalities 
both objectively and subjectively, with the latter being assessed by the personal feeling of general well-being.

The first part of the article examines the objective part of the research question: which employment pattern changes have been caused by the Covid-19 crisis? The main focus is on the changes in the gender composition of flexible employment forms that hold the potential to bring long-lasting changes to the labour market. The previously non-exhausted potential held by flexible employment can be assessed, with the caveat that any negative side-effects of such changes, whereby inequality is increased, not reduced, must be detected and actively addressed.

The second part explores the impact flexibility brings with respect to subjective well-being (SWB). Based on more positive evaluations of SWB, the changes may be considered as holding sufficient support to warrant keeping them in the long term, including after the Covid-19 crisis ends. A related research question is: do these changes, particularly those evaluated negatively due to increasing stress and uncertainty, affect all societal groups equally? Once again, here we are especially interested in how gender inequality is affected.

\section{Review of existing studies and formulation of the hypotheses}

There are positive and negative consequences of the transition to more flexible forms of employment in response to the recent pandemic. Negative consequences include those that highlight the precarious character of flexible employment. Flexibilisation in various forms, like self-employment, parttime job, teleworking, temporary contracts etc., when related to job instability, fear of losing one's job or non-voluntary work for a job offering less than full-time employment, may be considered to be precarious (Kanjuo-Mrčela and Ignjatović, 2015).

The shock to the economy, work and family life caused by the Covid-19 epidemic is unprecedented in recent history. The shock itself has provided a real-life setting for the analysis of the possible evolution of social phenomena by creating conditions where certain dependencies are emphasised. In this section, we review numerous articles that document and analyse various aspects of such changes.

Some studies show that the financial situation following the shock of the pandemic to the economy is becoming worse for those who were already facing financial difficulties, and better for those previously at an advantage (Wielogoszewska et al., 2020). 


\section{Changes in employment}

The same logic of the reproduction of social inequality during the crisis applies to gender inequality. Answering the objective part of the research question about structural changes in employment status, existing studies show overwhelming support for the claim that women are more vulnerable due to their less favourable starting position than men prior to the Covid19 outbreak. Their overall unstable employment status tends to suggest a more precarious character (as a push factor). The most recent studies in the area of gender inequality at work, generally covering the spring 2020 period of the economy's slowing, show that some gains made by way of reducing inequality both at work and in the division of family obligations from past decades are in retreat, which is alarming since this signals that the process of reducing gender disparities has perhaps reached a turning point (Eurofound, 2020a). The evidence shows that women more than men can expect to join in the rising unemployment, temporary lay-offs and reduced working hours, while there is a related fear of completely losing one's job. Involuntarily shortened work time also means lower incomes (European Institute for Gender Equality, 2017; Wielgoszewska et al., 2020; Möhring et al., 2020; Hipp and Bünning, 2020; Collins et al., 2020; Eurofound, 2020a).

\section{Overall consequences of the employment situation on SWB}

A positive aspect is that shorter working time can give more time for the family, provided that this does not conflict with the need to cover living necessities and ensure career advancement (Möhring et al., 2020). Yet women also disproportionally face the increased family and childcare demands more than men, acting as a pull factor away from actual labour activity. The deeply rooted, already existing everyday values and preferences where gender differences that also exist have moved into the foreground, following West and Zimmerman's 'doing gender theory' about culturally prescribed gender roles. A recent German study during the Covid-19 lockdown indicates that, even prospectively, while planning future work preferences cognitively, women have become less concerned about work matters than family ones. This might lead to greater inequality among those exposed to a heavier burden of family work and taking care of the children while striking a balance with one's regular job (Czymara et al., 2020). A Covid-19 study of a longitudinal cohort in the UK shows that mothers in particular have been disproportionally more involved in preschool and primary school child support during the lockdown (Villadsen et al., 2020).

In answer to the second part of our research question, the wider consequences of employment changes may be seen as largely negative with 
respect to gender inequality, given that we may expect the risk of worklife conflict to rise more among women, affecting their overall satisfaction with life. Unstable employment and the associated financial difficulties, possible or actual job loss, inappropriate housing conditions, health risks and reduced social contacts outside the household, related to either conditions of work or otherwise following the lockdown, are all negative aspects that are prevailing and reflected in lower work and family life satisfaction (Hipp and Bünning, 2020). Panel studies following the same individual over time are methodologically best suited to revealing the extent of changes in satisfaction caused by a changing family and work situation. Shortened work time imposed as a measure after the reduction of economic activity generally lowers work satisfaction, and family satisfaction for mothers, but not for fathers in one study in Germany, a country where shorter working time arrangements for women are common (Möhring et al., 2020).

\section{Working from home}

Studies of the working-from-home phenomenon dating from before the COVID-related lockdown describe it as an under-utilised possibility (EU JRC, 2020a). The transition to working from home is easier for those in highly paid occupations, which has been increasing the divide in existing inequalities between those able and those unable to afford to work from home (EU JRC, 2020b). The benefits of working from home are thus not accessible to many in manual occupations and people with low digital skills. Those who do not work from home are also mostly under the pressure of job and financial insecurity, as a Eurofond Covid-19 survey shows (EU JRC, 2020c). In Slovenia, the OECD's recommendations and related government response call for the active popularisation of this employment form. Obstacles to this that have been recognised include the rigid employment regulations and the managerial fear of losing control over the employees.

An overview of studies of those working from home contains reports of troubles with delineating work and private activities both physically and during the daytime, avoiding working beyond one's formal working hours, and deciding on when the working day will end etc. (Reuschke, 2019). Working from home as a specific flexible work arrangement has a mixed character by bringing positive and negative experiences selectively. One can devote more time to one's family and other activities performed at home, exercise greater work autonomy, use less time for commuting etc. Typical negative aspects include a tendency to work longer hours, to have fewer contacts with colleagues, and difficulty in arranging and balancing employment and housework and care activities (Kuhn et al., 2020). Particularly questionable are the measures to close schools since this has a potential negative effect for both 
children and employed parents, faced with the extra burden of assisting children with school work activities, more affecting Slovenia and similar countries where no caregiver is available in the household (Fuchs-Schündeln et al., 2020). 'Pandemic fatigue' is seen in reports of desperate parents as they describe their day-to-day routine of keeping work, children and the family together ${ }^{1}$.

While both men and women have reduced their work at the company's place of work, housework and involvement with childcare have marginally risen for women compared to men in a study in Spain, exacerbating the pre-Covid-19 unequal division of housework (Farré et al., 2020). Findings of a UK study confirm the disparity remains in childcare work for fathers and mothers who are regularly employed. Still, furlough schemes' changes to employment such as temporary lay-offs, job losses, and working from home have also seen a rise in fathers' involvement in the family, thereby tending to narrow the gender childcare gap and perhaps affecting future norms concerning the household division of work. Working from home can also be an opportunity for fathers, whose partners perhaps work in essential occupations and must be present in the workplace, to engage more in household and childcaring tasks (Sevilla and Smith, 2020).

The results of some panel studies show that those who work from home express reduced stress and hence positive life satisfaction, although this can be explained by the high earnings of those working from home (Kuhn et al., 2020). Homeworking broadly allows for greater flexibility in arranging family activities and leisure time. In this respect, it can generate more satisfaction for both parents and others if decided on voluntarily and not emerging as a necessity associated with the pandemic, and the closed schools and kindergarten. An overview of recent studies (Möhring et al., 2020) concludes the "relationship between remote work and job satisfaction remains unclear as previous results are contradictory". No clear increase/decrease in work and family satisfaction was found for parents required to work remotely, possibly compensating for the positive and negative aspects of the reconciliation of work and family life (Möhring et al., 2020). Eurofound survey results from April 2020 for all countries included shows the work-life balance is worsening for women more than for men while working from home. Additional family responsibilities prevent a greater share of women than men from concentrating on the job, but they also have trouble taking care of the family while working, and complain about stress (Eurofound, 2020a).

A review of recent studies leads to formulation of the following hypothesis, which may guide us as we explore whether and how gender inequality related to employment has been affected by the Covid-19 crisis in the country:

1 The report by Andraž K. in an article in Slovenske novice (14.12.2020). 
1. The changes in employment patterns in Slovenia in 2020 tend to increase gender inequality when observed objectively. The gender gap in employment is expected to widen. Unemployment rates, temporary absences from work, and forms of precarious flexible employment are expected to grow more among women than men.

2. The flexibility of employment, in particular work from home that has increased during Covid-19 in Slovenia, is expected to reward women less than men in terms of life satisfaction (SWB), with studies showing that women enjoy fewer of the gains arising from flexibility due to their disproportionally bigger involvement in family and childcare activities.

\section{Method and data}

The main source for detecting objective employment changes in the country in line with hypothesis 1 is the Labour Force Survey (LFS), coordinated by Eurostat and delivered by the Statistical Office of the Republic of Slovenia (SURS). Four times a year, a stratified simple random sample of around 7,600 inhabitants of Slovenia living in private households is used for the combined in-person, face-to-face and telephone interviewing of all household members. The size and quality of the data are comparable to an official mini-census. The time span allows for changes to be detected in labour force composition across years, and seasonal results to be compared, along with the situation in other countries in Europe to be contrasted with that in Slovenia.

The Covid-19 situation prevented home visits, which was compensated for with additional sample units, contacted by 'snail mail' and requesting a telephone number for an interview. The data collection difficulties due to the measures restraining Covid-19 in Slovenia led to a lower response rate in the 2 nd quarter of 2020 of $49 \%$ compared to the average response rate in 2019 of $77.7 \%$ (Rutar and Tomažič, 2020). Despite the difficulties in collecting data during the epidemic, the LFS survey may still be considered to be the most reliable data source for detecting employment conditions.

The LFS analysis is partially based on the authors' requested specifications for descriptive tables that were then delivered by SURS' experts with access to microdata ${ }^{2}$ in cases where the specifications exceeded the range of options allowed for in on-line analysis of the SiStat (Statistical Office, 2021) database. The equivalent Eurostat (2021a) data browser portal was utilised for an international comparison, allowing for an original custommade descriptive analysis.

2 We thank Dolores Trol and Marko Tomažič for support in providing the tables specified by the authors 
With the aim to explore through the second hypothesis how the individual's employment situation affects the SWB, controlling for the background factors and with an emphasis on gender differences, the Slovenian Public Opinion (Slovensko javno mnenje - SJM) was utilised. The main dependent variable was the assessment of life satisfaction measuring SWB, while the main independent variable was a description of the employment situation during the epidemic. The control variables were selected from the extensive set of demographic variables that forms a standard part of the SJM survey. In the multivariate part of the analysis, only existing control variables could be utilised, with the omitted variables having an unknown effect on the results. The following variables were selected: age, education, family situation characterised by the pre-schooler or schoolchild presence, and sector and permanence of employment ${ }^{3}$.

SJM is a leading academic survey in Slovenia that relies on a sample of individuals over the age of 18 years living in private households in the territory of Slovenia and follows a two-stage stratified random selection procedure from the Central Register of Population. A combination of online and postal self-completed surveys was used to collect the data in the period of lockdown between 1 April and 31 May 2020. The response rate was 44.4\%, quite high considering the situation (Hafner Fink, 2020).

The survey is cross-sectional and thus does not allow for causality to be established by the temporal ordering of cause and effect. This limits the findings' generalisability compared to certain existing studies mentioned, such as those referred to in the literature that use panel studies of the same persons followed at points in time.

The analysis consists of a descriptive presentation of the results and the final ordinary regression multivariate analysis, which is exploratory in character, based on correlations among the variables. The results of the analysis are described in the next section along with a discussion of the meaning the findings hold for the research questions.

\section{Results and discussion}

\section{Changes in employment during the lockdown in Slovenia}

Slovenia introduced a furlough compensation scheme in 2020 with the aim to prevent mass unemployment, thus those who were temporarily laidoff were compensated for a large part of their income. Despite the containment measures, the economy's slow-down and uncertainty led to changes in

3 For a description of the variables and question wording in the Data description section of the Codebook, see Hafner-Fink et al., 2020. 
unemployment, employers reduced hiring while temporary work contracts were not prolonged, similar to other countries around the world (Eurostat, 2020a; ILO, 2021). The employment situation consists of increasing shares of previously regularly employed to working from home, taking care of children and having temporary lay-offs, indicating that part of the workforce and their dependent families have also suffered economically.

\section{Employment, unemployment and temporary lay-offs}

To establish whether changes occurred in the structure and type of employment with respect to the first hypothesis, we start by examining the expectations that the gender gap will widen in Slovenia. While "Closing gender gaps in the labour market" is a goal of the Work-Life Balance Directive (Communication from the Commission, 2020), the tendency during the pandemic has been reversed in some eurozone countries we took for comparison to evaluate similarity in responses to the Covid-19 crisis. Slovenia has kept quite a balanced ratio of male/female employment over the last 20 years, as shown by quarterly LFS survey results ${ }^{4}$, corresponding to around a 10-percentage-point gap between the sexes. In comparison, the employ-

584 ment gap stagnated at about $12 \%$ in the eurozone countries after 2014, similarly to what happened in Slovenia 20 years ago.

The latest figures for 2020 are interesting for drawing conclusions on Covid-19's effect in comparison with 2019, with the LFS survey showing that employment opportunities in Slovenia saw a sharper reduction for women than men in the second quarter, when the gap exceeded $10 \%$. The employment rate remained stable in three quarters of 2020 for men, but dropped by 1.6\% in Q2 for women, followed by a quick return to the usual level in Q3 (Graph 1, A). A decrease in the female employment rate by more than a $1 \%$ difference in Q2 was only observed in a few other EU countries (Eurostat, 2020a).

The unemployment rate grew by $1.4 \%$ (from $4.7 \%$ to $5.9 \%$ ) for women and remained on that level even in the third quarter of 2020. Seasonally, one would expect the figures to change in the reverse direction from the first to the second quarter (Graph 1, B). Another source of data, average registered unemployment for 2020, saw a $14.6 \%$ increase over 2019, while for December 2020 over December 2019 it rose by 15.9\% (Zavod RS za zaposlovanje, 2020). Comparing registered unemployment between men and women in January 2020 shows $7.7 \%$ for men and $8.7 \%$ for women, while in December 2020 it was $7.8 \%$ for men and $9.7 \%$ for women, confirming the

4 Own calculations based on Eurostat (2020a) data: Total employment (resident population concept - LFS), age 15-64 years, unadjusted data (i.e. neither seasonally nor calendar-adjusted data). 
more unfavourable conditions for women in line with the LFS results presented above. Comparable figures for euro area countries reveal a stable situation for men and even a drop in unemployment for women (Graph 1, B).

Graph 1, A and B: EMPLOYMENT [LFSI_EMP_Q] AND UNEMPLOYMENT [LFSQ_

URGAN] RATES BY SEX (\%)

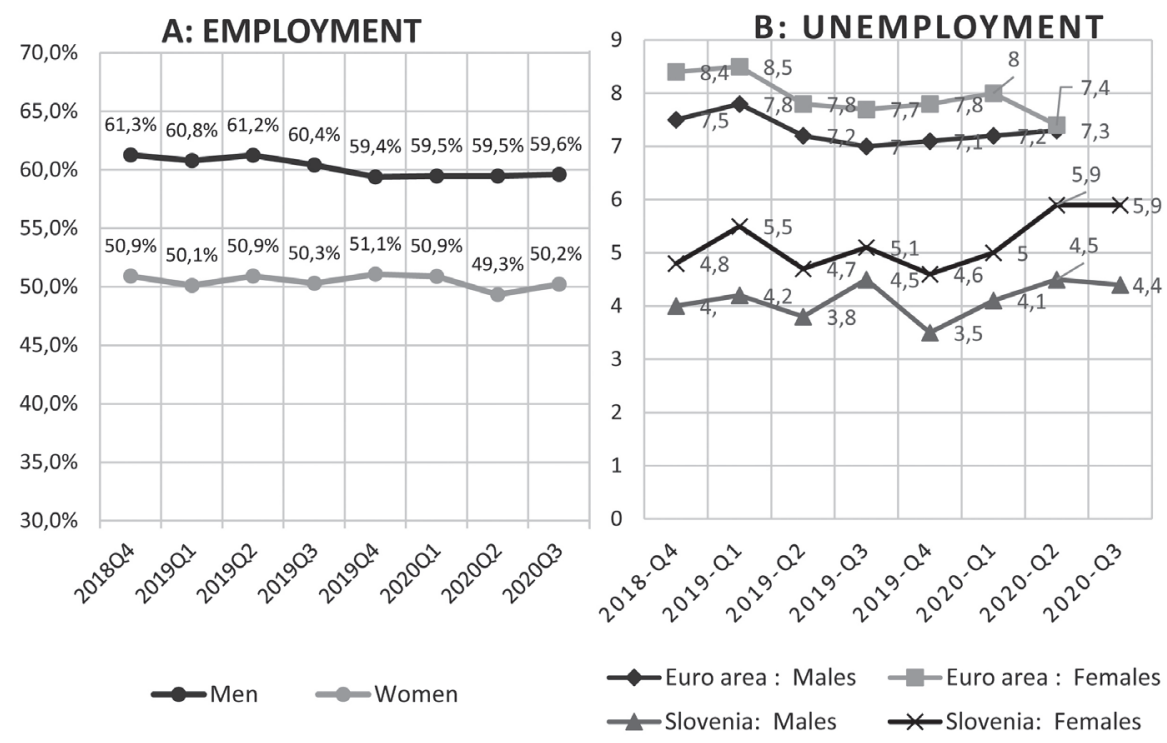

Source: Statistical Office of the Republic of Slovenia and Eurostat: Labour Force Survey.

All in all, the employment situation slightly worsened for women in Slovenia, revealing that, despite the compensation measures introduced into the labour market, the disparities between the sexes sharpened in Slovenia more than in most other comparable EU countries regarding both total employment and the unemployment rate among the labour force.

While temporary absences from work are mostly voluntarily, for instance holidays and parent leave, during the lockdown involuntary changes in employment have occurred such as lay-offs. Absences from work shows a clear widening of the gender gap. From mid-March to the end of April 2020, the ratio of men-to-women absences exceeded the average for 2015-2019 among all EU countries by over 20 percent points (Eurostat, 2020b; Eurostat, 2021b). In Slovenia, our own analysis based on the SiStat database reveals women's total absences rose in Q2 more than those of men and remained high compared to men in Q3 (Graph 2). 
Graph 2: ABSENCE FROM WORK (TOTAL AND BY REASON) BY GENDER, LFS

QUARTERLY DATA, SLOVENIA

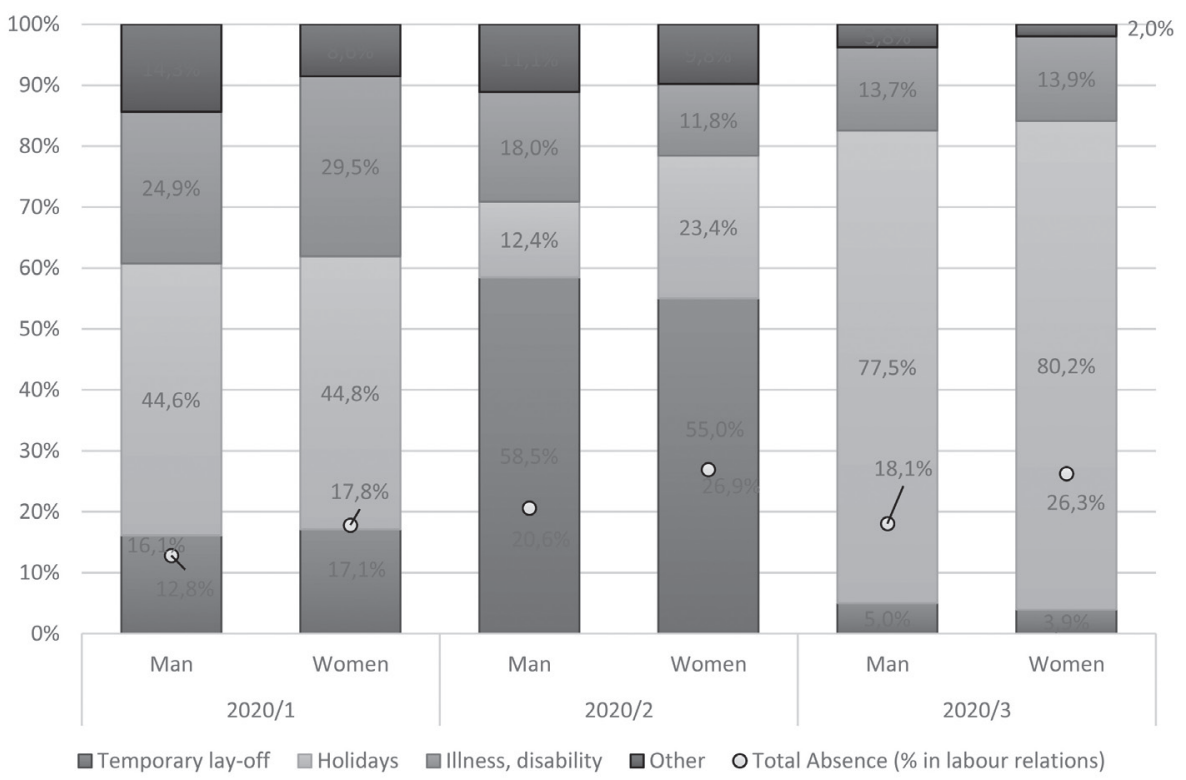

Source: Statistical Office of the Republic of Slovenia: Labour Force Survey.

Intervention laws ZIUPPP and ZIUZEOP, ZIUZEOP-A - figures for March-May 2020 show monthly temporary lay-offs were around 20\%, while in the second half of 2020 temporary lay-offs accounted for less than $10 \%$ of the employed 5 .

\section{Flexibility at work}

In the last decade, the labour market in Slovenia has tended to contain more flexible and precarious employment, partially due to the global economic crisis 10 years ago (Ignjatović and Kanjuo Mrčela, 2017). This tendency converged with the Covid-19 crisis that has selectively hit some flexible types of work more than others. The largest fall in employment during the first wave of the Covid-19 lockdown was in student work (Graph 3).

5 ZRSZ, NEURADNI PODATKI, accessible at https://www.ess.gov.si/files/13227/Neuradni_dnevni_ podatki_brezposelnost.pdf, 10. 1.2021. 
Graph 3: TYPE OF WORK (PROFESSIONAL STATUS) BY GENDER (\% OF TOTAL EMPLOYED), LFS QUARTERLY DATA, SLOVENIA

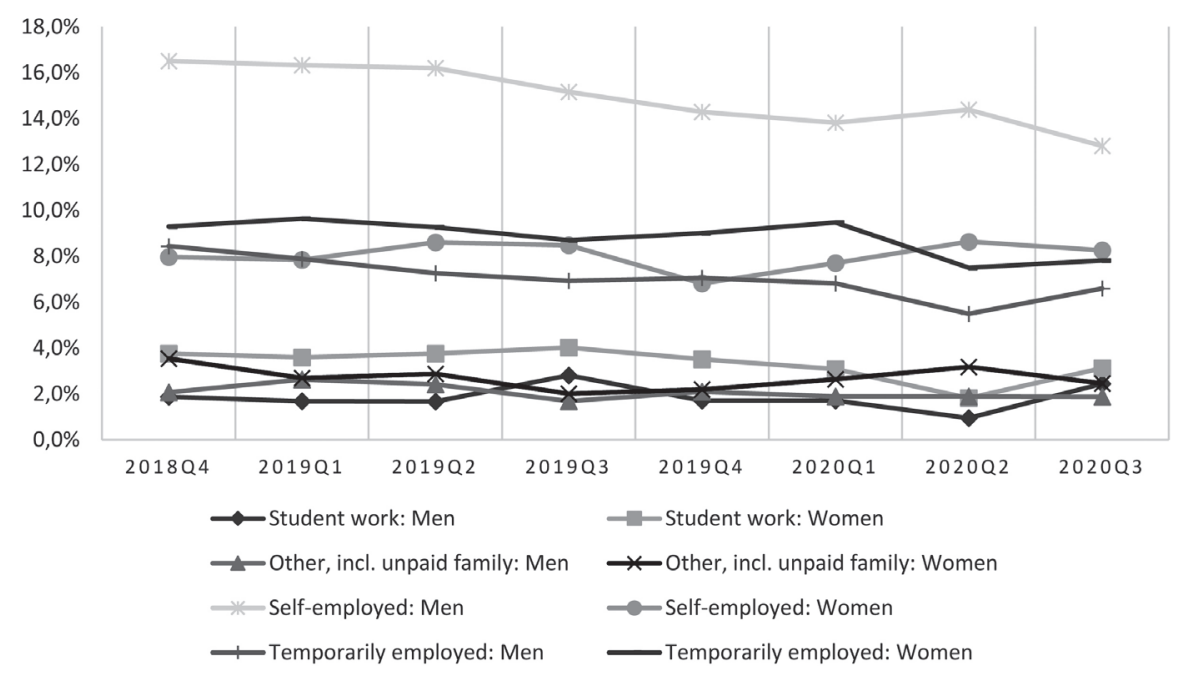

Source: Statistical Office of the Republic of Slovenia: Labour Force Survey.

Two other forms of 'flexible' employment, such as temporary employment and self-employment, have proven to be flexible indeed during the crisis in the sense that both have also faced a reduction. The most prevalent of all flexible forms is self-employed men, which already starts falling in the third quarter of 2019 from the previous figure above 16\%. Self-employed men's jobs saw a 10\% decline in the share of Q2 2019 over Q2 2020, and even more in a Q3 2019/20 comparison (change rate of 16\%) in the period reaching the lowest figure of $12.8 \%$, while women's self-employed numbers remained stable. Corresponding European countries' change for the self-employed shows that Slovenia does indeed exceed all other EU countries (Eurostat, 2020c). Temporarily employed men and women both face a steep decline in Q2, which is partly preserved in Q3 compared to the previous year (Graph 3).

\section{Part-time work}

In the third intervention law in Slovenia (ZIUOOPE) for the period 12. 6. 2020 to 30. 12. 2020, a furlough scheme for supporting less than full-time work in Slovenia covered 68,000 people, while the seventh intervention law (ZIUPOPDVE), for the period after 31.12.2020, covered 20,000 people, namely, less than 3\%. 
Table 1: PART-TIME WORK BY GENDER (\% OF LABOUR FORCE), LFS QUARTERLY DATA, SLOVENIA

\begin{tabular}{|l|c|c|c|c|c|c|c|}
\hline & $2019 / 1$ & $2019 / 2$ & $2019 / 3$ & $2019 / 4$ & $2020 / 1$ & $2020 / 2$ & $2020 / 3$ \\
\hline Men & $5.9 \%$ & $5.6 \%$ & $5.3 \%$ & $5.2 \%$ & $5.3 \%$ & $5.5 \%$ & $6.2 \%$ \\
\hline women & $13.4 \%$ & $13.4 \%$ & $12.4 \%$ & $13.0 \%$ & $13.1 \%$ & $11.7 \%$ & $13.6 \%$ \\
\hline Total & $9.3 \%$ & $9.2 \%$ & $8.5 \%$ & $8.8 \%$ & $8.9 \%$ & $8.3 \%$ & $9.6 \%$ \\
\hline
\end{tabular}

Source: Statistical Office of the Republic of Slovenia: Labour Force Survey.

Regarding changes to part-time work, the LFS data show a decline of about 2\% for women in Q2 2020 compared to Q1, which was immediately compensated for in Q3 in contrast to a gradual rise of $1 \%$ for men in the whole past Q1 period. If anything, these fluctuations show that for women part-time work is a less stable employment form, and not so much a desired form in Slovenia, with double-earner couples being the norm compared to some European countries. Part-time work is primarily offered in Slovenia as a company policy and often the only employment opportunity for first-time employees (Lapornik et al., 2019).

\section{Work from home prevalence}

In the last decade, working from home has also been becoming more prevalent in Slovenia as the share of those who never usually work from home has dropped by about 10\% (own calculation, Graph 4). In this respect, Slovenia is just above the EU-27 average, but still achieves less than half the levels of the northern European countries, where the share of working from home exceeds 30\% (EU JRC, 2020a). Resistance to allowing work from home is seen in the non-adapted regulation, management culture and organisational settings. Even in the public administration sector, organisational culture varies in Slovenia, not permitting a considerable share of employees to work from home (Zalaznik, 2020). Employers' trust related to work autonomy is a factor here (EU JRC, 2020c).

Working from home more than doubled after the first wave of the pandemic in Slovenia and reached over $40 \%$ of the employed for women, revealing unexhausted potential compared to the pre-pandemic levels. Working from home is engaged in by $10 \%$ more women than men (own calculations based on Eurofound 2020c). This nearly exactly corresponds to the shares of working from home compared to working at the workplace, if we compare only those categories from the SJM survey (Table 2), with 31\% of men versus $43 \%$ of women working from home. This pattern may reflect the voluntary-preference-related greater willingness of women to work from home, to ease the balancing of family care and work, which as we saw in the literature review brings an extra burden. 
Graph 4: EMPLOYED PERSONS NEVER WORKING FROM HOME AS A

PERCENTAGE OF TOTAL EMPLOYMENT, BY GENDER (\%) [LFSA_ EHOMP], LFS QUARTERLY DATA, SLOVENIA

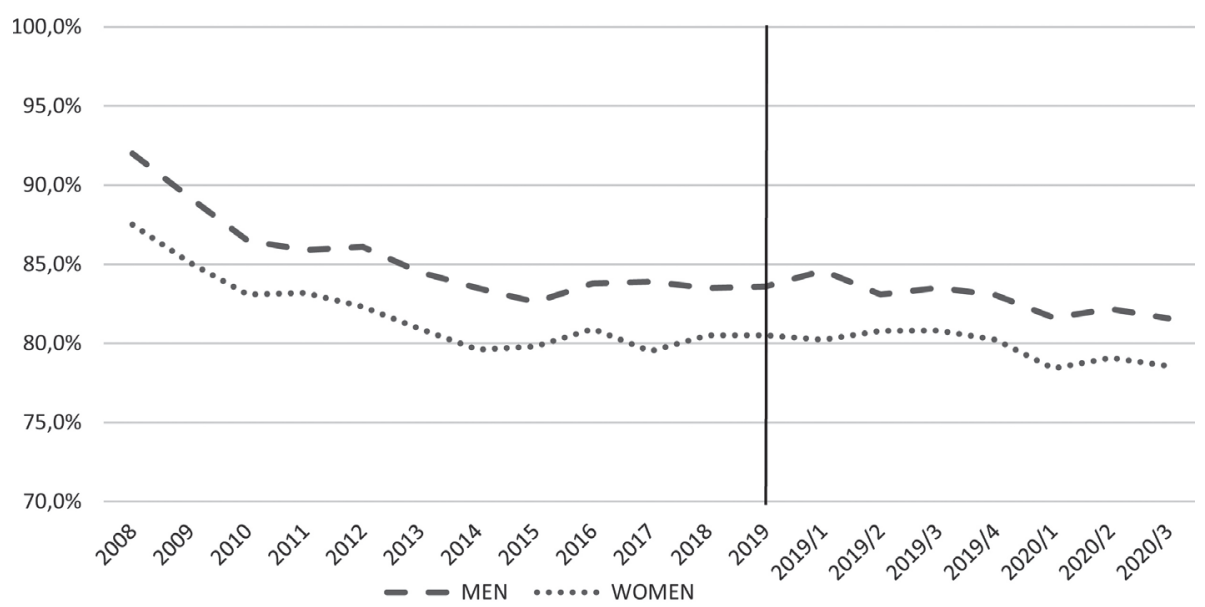

Source: Statistical Office of the Republic of Slovenia: Labour Force Survey.

\section{Consequences of the changes in employment based on subjective evaluations}

To introduce the second part of the results about how the employment situation has affected subjective evaluations in terms of the second hypothesis, the distributions of the SJM sample are presented (Table 2). The descriptive results roughly confirm the previously detected employment situation distribution during the COVID-related lockdown in the epidemic's first wave in spring 2020. Women marginally more than men are working from home and dominate among temporary lay-offs. Following our problem setting in the introduction, this situation reflects both push factors - employment occupations and sectors dominated by women - and pull factors out of regular work related to the increased family obligations, which are probably unequally distributed among couples, as suggested by the literature review. The youngest age of those below 30 years is affected the most by the temporary lay-off arrangements, chiefly reflecting the presence of precarious occupational statuses. The highest education degree occupations stand out with working from home arrangements being possible, while involuntary lay-offs and working at the regular workplace is a tendency for employees with a lower education. 
Table 2: EMPLOYMENT SITUATION SHARE IN PERCENT BY GENDER, AGE GROUP AND EDUCATION, APRIL - MAY 2020, SLOVENIA, SJM2O2O/1

\begin{tabular}{|c|c|c|c|c|c|c|}
\hline & \multicolumn{4}{|c|}{ Employment situation during the epidemic? } & \multirow[b]{2}{*}{ Total } & \multirow[b]{2}{*}{ Nonactive } \\
\hline & $\begin{array}{l}\text { Regular } \\
\text { work }\end{array}$ & $\begin{array}{l}\text { Work from } \\
\text { home }\end{array}$ & $\begin{array}{c}\text { Temporary } \\
\text { lay-off }\end{array}$ & Other* & & \\
\hline Frequency & 223 & 127 & 153 & 65 & 568 & 285 \\
\hline Valid Percent & $39 \%$ & $22 \%$ & $27 \%$ & $12 \%$ & $100 \%$ & \\
\hline Gender & & & & & & $\mathrm{N}=$ \\
\hline Men & $46 \%$ & $21 \%$ & $22 \%$ & $11 \%$ & $100 \%$ & 297 \\
\hline Women & $32 \%$ & $24 \%$ & $33 \%$ & $12 \%$ & $100 \%$ & 270 \\
\hline \multicolumn{7}{|l|}{ AGE } \\
\hline 29 years or less & $28 \%$ & $14 \%$ & $49 \%$ & $9 \%$ & $100 \%$ & 90 \\
\hline 30 up to 49 years & $41 \%$ & $23 \%$ & $24 \%$ & $13 \%$ & $100 \%$ & 289 \\
\hline 50 years or more & $42 \%$ & $26 \%$ & $22 \%$ & $11 \%$ & $100 \%$ & 188 \\
\hline \multicolumn{7}{|l|}{ EDUCATION } \\
\hline Vocational or less & $53 \%$ & $6 \%$ & $34 \%$ & $8 \%$ & $100 \%$ & 125 \\
\hline Middle & $43 \%$ & $11 \%$ & $36 \%$ & $10 \%$ & $100 \%$ & 204 \\
\hline Upper & $29 \%$ & $41 \%$ & $16 \%$ & $14 \%$ & $100 \%$ & 237 \\
\hline
\end{tabular}

Note: Other: combination of child care absence, while employed or not, illness, holidays Source: Hafner-Fink et al., 2020.

\section{Bivariate subjective satisfaction with life, finances, trust and health}

The bivariate results (Table 3) of various satisfaction indices show a general pattern whereby those who work from home are the most satisfied with life and also trust the most, being materially better off. The biggest contrast is with temporary lay-offs, namely, the situation that is the most uncertain in all respects, except health. Job and financial insecurity are obviously related to this status. Similar precariousness expressed in material uncertainty is temporary employment status.

Parents of both sexes with young children are most satisfied with different aspects of life, showing that the partner's presence is one of the most robust factors of happiness, as is education, generally related to higher income and higher occupational social status. In bivariate analysis, little difference is shown regarding gender; the most prominent negative is the expression of one's own health worries.

\section{Subjective life satisfaction and employment situation for women and men}

Multivariate analysis on the whole population of satisfaction with life shows that differences in satisfaction levels - between those who Work from home as the most satisfied and Lay-offs as the least satisfied, while those working at the workplace are in-between - are largely dominated by 
Table 3: SUBJECTIVE EVALUATIONS (MEANS) BY EMPLOYMENT CONDITIONS AND GENDER, AGE GROUP AND EDUCATION, APRIL - MAY 2020, SLOVENIA, SJM2O2O/1

\begin{tabular}{|c|c|c|c|c|c|}
\hline & $\begin{array}{l}\text { Z1 Life } \\
\text { satisfaction }\end{array}$ & $\begin{array}{l}\text { Z3 } \\
\text { Satisfaction } \\
\text { with } \\
\text { material } \\
\text { conditions }\end{array}$ & $\begin{array}{l}\text { Z4 Financially } \\
\text { better off } \\
\text { compared to } \\
\text { other people } \\
\text { around ... }\end{array}$ & $\begin{array}{l}\text { Z5 General } \\
\text { trust }\end{array}$ & $\begin{array}{l}\text { K16a } \\
\text { Own health } \\
\text { worries }\end{array}$ \\
\hline $\mathrm{N}$ & 562 & 564 & 530 & 565 & 560 \\
\hline Minimum & $\begin{array}{c}0-\text { not } \\
\text { satisfied }\end{array}$ & $\begin{array}{c}0-\text { not } \\
\text { satisfied }\end{array}$ & 0 - better & $\begin{array}{c}0-\text { cannot } \\
\text { trust }\end{array}$ & $\begin{array}{c}1-\text { few or } \\
\text { no worries }\end{array}$ \\
\hline Maximum & $\begin{array}{c}10- \\
\text { completely } \\
\text { satisfied }\end{array}$ & $\begin{array}{c}10- \\
\text { completely } \\
\text { satisfied }\end{array}$ & $10-$ worse & $\begin{array}{c}10 \text { - trust } \\
\text { completely }\end{array}$ & $\begin{array}{l}5 \text { - a lot } \\
\text { worries }\end{array}$ \\
\hline Mean & 7.0 & 6.8 & 5.9 & 4.5 & 3.1 \\
\hline Std. Deviation & 2.1 & 2.1 & 1.9 & 2.6 & 1.3 \\
\hline \multicolumn{6}{|l|}{ Active population } \\
\hline Regular work & 6.9 & 6.6 & 5.9 & 4.3 & 3.1 \\
\hline Work from home & 7.6 & 7.5 & 6.6 & 5.2 & 3.0 \\
\hline Temporary lay-off & 6.4 & 6.3 & 5.0 & 4.1 & 2.9 \\
\hline Other & 7.5 & 7.1 & 6.5 & 4.6 & 3.2 \\
\hline \multicolumn{6}{|c|}{ D5a Employment contract } \\
\hline 1 permanent & 7.1 & 6.9 & 6.1 & 4.5 & 3.1 \\
\hline 0 temporary & 7.0 & 6.6 & 5.5 & 4.8 & 2.9 \\
\hline \multicolumn{6}{|l|}{ Gender } \\
\hline Men & 6.9 & 6.7 & 5.8 & 4.4 & 2.9 \\
\hline Women & 7.1 & 6.9 & 5.9 & 4.6 & 3.2 \\
\hline \multicolumn{6}{|l|}{ AGE } \\
\hline 29 years or less & 7.0 & 7.2 & 5.6 & 4.4 & 2.7 \\
\hline 30 up to 49 years & 7.1 & 6.9 & 6.0 & 4.4 & 2.9 \\
\hline 50 years or more & 6.8 & 6.4 & 5.8 & 4.7 & 3.4 \\
\hline \multicolumn{6}{|l|}{ EDUCATION } \\
\hline Vocational or less & 6.3 & 6.0 & 5.2 & 3.3 & 3.2 \\
\hline Middle & 6.8 & 6.5 & 5.4 & 4.2 & 3.1 \\
\hline Upper & 7.5 & 7.5 & 6.6 & 5.3 & 2.9 \\
\hline \multicolumn{6}{|c|}{ Gender (Men/Women) and D29 (Pre)school child in family } \\
\hline $1 \mathrm{M}$ no child & 6.7 & 6.7 & 5.8 & 4.3 & 3.0 \\
\hline $2 \mathrm{M}$ school age & 7.1 & 6.5 & 5.8 & 4.0 & 3.0 \\
\hline $3 \mathrm{M}$ preschool age & 7.4 & 7.3 & 6.0 & 5.1 & 2.7 \\
\hline $4 \mathrm{~W}$ no child & 6.7 & 6.8 & 5.9 & 4.5 & 3.1 \\
\hline $5 \mathrm{~W}$ school age & 7.0 & 6.7 & 5.6 & 4.3 & 3.3 \\
\hline $6 \mathrm{~W}$ preschool age & 8.0 & 7.4 & 6.4 & 5.3 & 3.4 \\
\hline
\end{tabular}

Source: Hafner-Fink et al., 2020.

the presence of a school/preschool child and education. Those with a lower status job that requires less than a high school education are forced by the Covid-19 situation to involuntarily lay-off at home, while occupations with 
a higher education allow working from home. The presence of a child, as a pull factor for some parents to prefer to work from home, alone brings greater satisfaction with life, with no additional bonus of working at home.

Table 4: REGRESSION COEFFICIENTS OF LIFE SATISFACTION BY EMPLOYMENT SITUATION AND CONTROL VARIABLES FOR THE ACTIVE POPULATION AND SEPARATED FOR MEN AND WOMEN APRIL - MAY 2O2O, SLOVENIA, SJM2O2O/1

\begin{tabular}{|c|c|c|c|c|c|c|c|c|c|c|c|c|}
\hline \multirow{6}{*}{$\begin{array}{c}\text { Dependent } \\
\text { Adjusted R } \\
\text { Square } \\
\text { R Square } \\
\text { Model Sig. }\end{array}$} & \multirow{2}{*}{\multicolumn{2}{|c|}{\begin{tabular}{|c|} 
MODEL 1 \\
Z1 - Whole \\
population
\end{tabular}}} & \multirow{2}{*}{\multicolumn{2}{|c|}{$\begin{array}{c}\text { MODEL } 2 \\
\text { Z1 - Whole } \\
\text { population }\end{array}$}} & \multirow{2}{*}{\multicolumn{2}{|c|}{$\begin{array}{c}\text { MODEL } 1 \\
\text { Z1 } \\
\text { - Men }\end{array}$}} & \multirow{2}{*}{\multicolumn{2}{|c|}{$\begin{array}{c}\text { MODEL } 2 \\
\mathrm{Z1} \\
- \text { Men } \\
\end{array}$}} & \multirow{2}{*}{\multicolumn{2}{|c|}{$\begin{array}{c}\text { MODEL 1 } \\
\text { Z1 - } \\
\text { Women }\end{array}$}} & \multirow{2}{*}{\multicolumn{2}{|c|}{$\begin{array}{c}\text { MODEL } 2 \\
\text { Z1 - } \\
\text { Women }\end{array}$}} \\
\hline & & & & & & & & & & & & \\
\hline & & \multicolumn{2}{|l|}{.08} & \multicolumn{2}{|l|}{.05} & \multicolumn{2}{|l|}{.10} & \multicolumn{2}{|c|}{.04} & \multicolumn{2}{|l|}{.03} \\
\hline & \multicolumn{2}{|l|}{.05} & & \multicolumn{2}{|c|}{.06} & & \multicolumn{2}{|l|}{.05} & \multicolumn{2}{|l|}{.07} \\
\hline & \multicolumn{2}{|c|}{$.000^{\mathrm{b}}$} & \multirow{2}{*}{\multicolumn{2}{|c|}{$\begin{array}{l}.000^{\mathrm{b}} \\
\mathrm{SC}\end{array}$}} & \multirow{2}{*}{\multicolumn{2}{|c|}{$\begin{array}{l}.001^{\mathrm{b}} \\
\mathrm{SC}\end{array}$}} & \multirow{2}{*}{\multicolumn{2}{|c|}{$\begin{array}{l}.000^{\mathrm{b}} \\
\mathrm{SC}\end{array}$}} & \multirow{2}{*}{\multicolumn{2}{|c|}{$\begin{array}{l}.004^{\mathrm{c}} \\
\text { S C }\end{array}$}} & \multirow{2}{*}{\multicolumn{2}{|c|}{$\begin{array}{l}.116^{c} \\
\text { S C }\end{array}$}} \\
\hline & \multicolumn{2}{|l|}{$\mathrm{SC}$} & & & & & & & & & & \\
\hline & B & Sig. & \multicolumn{2}{|l|}{$B$} & \multicolumn{2}{|r|}{ Sig. } & \multicolumn{2}{|r|}{ Sig. } & \multicolumn{2}{|r|}{ Sig. } & B & Sig. \\
\hline (Constant) & 6,9 & 0 & 5,6 & 0 & 6,8 & 0 & 5,8 & 0 & 7,071 & 0 & 5,9 & 0 \\
\hline $\begin{array}{l}\text { Regular work } \\
\text { (omitted) }\end{array}$ & 0 & & 0 & & 0 & & 0 & & 0 & & 0 & \\
\hline $\begin{array}{l}\text { Work from } \\
\text { home }\end{array}$ & .7 & .004 & .2 & .32 & 9 & .005 & .5 & .165 & .4 & .285 & .1 & .86 \\
\hline Lay-off & -.5 & .013 & -.2 & .474 & -.6 & .058 & -.3 & .392 & -.6 & .057 & -.1 & .84 \\
\hline Other & .6 & .049 & .0 & .918 & 3 & .42 & -.3 & .521 & .7 & .075 & 3 & .49 \\
\hline $\begin{array}{l}\text { D8_Public } \\
\text { Sector }\end{array}$ & & & -.3 & .081 & & & -.7 & .02 & & & .0 & .88 \\
\hline $\begin{array}{l}\text { D5aPerma- } \\
\text { nent empl. }\end{array}$ & & & .1 & .739 & & & .0 & .904 & & & .1 & .79 \\
\hline $\begin{array}{l}\text { D28_D29 } \\
\text { Preschool or } \\
\text { school child }\end{array}$ & & & .6 & .002 & & & .6 & .043 & & & .6 & .03 \\
\hline $\begin{array}{l}\text { Female } \\
(\text { male }=0)\end{array}$ & & & .3 & .133 & & & & & & & & \\
\hline $\begin{array}{l}29 \text { years or } \\
\text { less }\end{array}$ & & & .3 & .435 & & & -.3 & .556 & & & .7 & .1 \\
\hline $\begin{array}{l}30 \text { up to } 49 \\
\text { years ( } 50+ \\
\text { omitted) }\end{array}$ & & & -.2 & .336 & & & -.5 & .087 & & & .1 & .7 \\
\hline $\begin{array}{l}\text { Upper } \\
\text { education }\end{array}$ & & & .6 & .000 & & & .6 & .000 & & & .3 & .08 \\
\hline
\end{tabular}

Source: Hafner-Fink et al., 2020.

A similar pattern can be observed for the sample of men, with working from home bringing even more satisfaction, about half a point higher (yet not significant due to the smaller sample size) compared to those staying in the workplace, also after control variables are introduced. For the sample of women, working from home is already less satisfying in model 1 , and shows no effect after the control variables are introduced. These results tend to 
support the second hypothesis that women find working from home less rewarding than men do, after other variables are controlled for, with the positive aspects possibly being reduced by additional difficulties with combining work and family matters.

\section{Conclusion}

Limitations of the study include the fact that these are the results of a cross-section analysis and we cannot determine the temporal order of the variables to establish causality, nor can we assess the effects of changes in the employment situation on SWB by directly comparing the pre- and during-epidemic data following the same persons. The multivariate analysis results are mainly exploratory in character as omitted factors remain that were not accounted for since the lack of appropriate variables prevented us from so doing.

We carefully collected the existing evidence with regard to the research question of whether the changes in employment patterns during the Covid19 period show increasing gender inequalities. The drop in employment and rise in absences from work and unemployment for women exceeding those for men in Slovenia, which is even sharper than observed in most other European countries, indicate the tendency for greater inequality between genders and threaten a wider gender gap in employment. This confirms our expectations expressed in the first hypothesis about the growing gender gap. As the results of some preliminary analyses show in other countries, this tendency is partly driven by family and childcare demands being unequally shared between partner parents (c.f. Hipp and Bünning, 2020).

The drops in flexible employment forms were distributed equally for both sexes, except that women remained in less favourable positions in temporary employment status in the third quarter after the peak of the Covid19 lockdown, while among men self-employed status continues to be the most unfavourable. It is hard to conclude that gender inequalities are growing in all employment arrangements, thus only partially confirming our first hypothesis. Divergent tendencies occur, some driven by the changes that the epidemic brings to different sectors of the economy, and others following existing, more deeply-rooted social inequalities. However, perhaps the otherwise hidden negative tendencies in certain fields deserve attention to prevent them from continuing in the future.

Some flexible employment forms are chosen in Slovenia as less than a voluntary decision, such as part-time work in the context of the full-time employment norm, and the need for both couples to add to the family income. As such, part-time work, having shown little growth in 2020 in 
Slovenia, and more often being the case for women, can be evaluated as more a negative than a positive development.

Working from home, as another flexible employment form, itself holds the greatest potential in a positive direction for the future work of both sexes. The prospects also look bright since working from home is more prevalent among women, with the results of numerous analyses showing that preferences for working from home are stronger among women. Still, the burden of additional family care activities and the need to combine with work is seen more on the side of women, which again may be seen as confirming the hypothesis on growing gender inequality. Special consideration should accordingly be paid to the orientation of policy measures so as to prevent additional inequalities from occurring.

Involuntary temporary lay-offs indicate employment and financial insecurity, as confirmed by results showing that both sexes have the lowest subjective satisfaction levels, whose background in contrast to those working at home is a lower social status. Limited choice is available in some precarious employment forms, such as the self-employed, the young generation's student work for example, or temporary contracts that were not prolonged due to companies reducing their activities. The otherwise hidden existing 594 inequalities in life chances, not only those based on gender, have been uncovered by the crisis.

The final results for the subjective evaluations of life satisfaction again confirm the main results of other studies, thereby supporting our second hypothesis: the positive and negative aspects of flexibilisation overall are less favourable for women. The primary conclusion is that na ve and simplified considerations about flexibilisation are inappropriate as background factors like social status affect one's possibilities - like working from home being a privilege of the more educated, especially men.

The chaotic character of some of the structural employment changes that, when combined, lead to increased gender inequality, as the findings have shown, call for careful additional measures to prevent these inequalities from continuing. The crisis itself also brings, as an unintended consequence, an opportunity for parents of both sexes to reshape their attitudes and habits as concerns reconciling family and work life, the area for which especially fathers need additional policy encouragement (ILO, 2020). If the positive experiences are reinforced and negative ones eased with a deliberate policy response, this may prevent a widening of gender disparities (c.f. Sevilla and Smith, 2020; Farré et al., 2020; Eurofound, 2020). In the short run, the prolonged closure of schools and kindergartens due to the pandemic must also be seen for the outcomes it holds for gender inequality through the additional burden of family care that it places on employed parents. 


\section{BIBLIOGRAPHY}

Collins, Caitlyn, Liana Christin Landivar, Leah Ruppanner, William J. Scarborough (2020): Covid-19 and the Gender Gap in Work Hours. Gender, Work and Organization 7.

Czymara, Christian S., Alexander Langenkamp and Tomás Cano (2020): Cause for Concerns: Gender Inequality in Experiencing the Covid-19 Lockdown in Germany. European Societies.

EU JRC (2020c): Telework in the EU Before and After the Covid-19: Where We Were, Where We Head to. EU Joint Research Centre. Accessible at https://ec.europa. eu/jrc/sites/jrcsh/files/jrc120945_policy_brief_-_covid_and_telework_final.pdf, 10. 1. 2021.

EU JRC (2020b): Who Can Telework Today? The Teleworkability of Occupations in the EU. EU Joint Research Centre. Accessible at https://ec.europa.eu/jrc/sites/ jrcsh/files/policy_brief_-_who_can_telework_today_-_the_teleworkability_of_ occupations_in_the_eu_final.pdf, 10.1.2021.

EU JRC (2020c): Teleworkability and the Covid-19 Crisis: A New Digital Divide? EU Joint Research Centre and Eurofound. Accessible at https://ec.europa.eu/jrc/ sites/jrcsh/files/jrc121193.pdf, 10. 1. 2021.

European Institute for Gender Equality (EIGE) (2017): Gender, Skills and Precarious Work in the EU: Research note. Vilnius: EIGE.

Farré, Lídia and Yarine Fawaz, Libertad González and Jennifer Graves (2020): How the Covid-19 Lockdown Affected Gender Inequality in Paid and Unpaid Work in Spain JULY 2020. Bonn, Germany: IZA - Institute of Labor Economics. DISCUSSION PAPER SERIES IZA DP No. 13434. Accessible at http://ftp.iza.org/ dp13434.pdf, 10. 1. 2021.

Fuchs-Schündeln, Nicola and Moritz Kuhn and Michèle Tertilt (2020): The ShortRun Macro Implications of School and Child-Care Closures. Bonn, Germany: IZA - Institute of Labor Economics. DISCUSSION PAPER SERIES IZA DP NO. 13353. Accessible at http://ftp.iza.org/dp13353.pdf, 10. 1. 2021.

Hafner Fink, Mitja, Slavko Kurdija, Brina Malnar, Marko Polič and Samo Uhan (2020): Slovenian Public Opinion 2020/1: Mirror of Public Opinion, Life and Attitudes During the Covid-19 Epidemic [Data file]. Ljubljana: University of Ljubljana, Slovenian Social Science Data Archives. ADP - IDNo: SJM201.

Hipp, Lena and Mareike Bünning (2020): Parenthood as a Driver of Increased Gender Inequality During Covid-19? Exploratory Evidence from Germany. European Societies.

Kanjuo-Mrčela, Aleksandra and Miroljub Ignjatović (2015): Od prožnosti do prekarnosti dela. Teorija in praksa 52 (3): 350-381.

Kuhn, Ursina, Hannah S. Klaas, Erika Antal, Nora Dasoki, Florence Lebert, Oliver Lipps, Gian-Andrea Monsch, Jan-Erik Refle, Valérie-Anne Ryser, Robin Tillmann and Marieke Voorpostel (2020): Who is Most Affected by the Corona Crisis? An Analysis of Changes in Stress and Well-being in Switzerland. European Societies.

Lapornik, Mija, Barbara Krivic, Iris Pensa and Nina Bakovnik (2019): Analiza o prednostih in slabostih zaposlitve za krajši delovni čas. Ljubljana: Ministrstvo za delo, družino, socialne zadeve in enake možnosti, Evropska unija in Trgovinska 
zbornica Slovenije. Accessible at https://www.tzslo.si/uploads/karmen/analizapzkdc.pdf, 10. 1. 2021.

Möhring, Katja, Elias Naumann, Maximiliane Reifenscheid, Alexander Wenz, Tobias Rettig, Ulrich Krieger, Sabine Friedel, Marina Finkel, Carina Cornesse and Annelies G. Blom (2020): The Covid-19 Pandemic and Subjective Wellbeing: Longitudinal Evidence on Satisfaction with Work and Family. European Societies. Accessible at https://doi.org/10.1080/14616696.2020.1833066, 10. 1. 2021.

Reuschke, Darja (2019): The Subjective Well-being of Homeworkers across Life Domains. Economy and Space 51 (6). Accessible at https://doi.org/10.1177/ 0308518X19842583, 10. 1. 2021.

Sevilla, Almudena and Sarah Smith (2020): Baby Steps: The Gender Division of Childcare during the Covid-19 Pandemic. Bonn, Germany: IZA - Institute of Labor Economics. DISCUSSION PAPER SERIES IZA DP No. 13302, Institute of Labor Economics, Bonn. Accessible at http://ftp.iza.org/dp13302.pdf, 10. 1. 2021.

Villadsen, Aase, Gabriella Conti and Emla Fitzsimons (2020): Parental Involvement in Home Schooling and Developmental Play during Lockdown - Initial findings from the Covid-19 Survey in Five National Longitudinal Studies. London: UCL Centre for Longitudinal Studies. Accessible at https://cls.ucl.ac.uk/wp-content/ uploads/2017/02/Parental-involvement-in-home-schooling-and-developmentalplay-during-lockdown-\%E2\%80\%93-initial-findings-from-Covid-19-survey.pdf, 10. 1. 2021.

Wielgoszewska, Bożena, Francis Green and Alissa Goodman (2020): Finances and Employment during Lockdown - Initial findings from the Covid-19 Survey in Five National Longitudinal Studies. London: UCL Centre for Longitudinal Studies in collaboration with the MRC Unit for Lifelong Health and Ageing (LHA). Accessible at https://cls.ucl.ac.uk/wp-content/uploads/2017/02/ Finances-and-employment-during-lockdown-\%E2\%80\%93-initial-findings-fromCovid-19-survey.pdf, 10. 1. 2021.

\section{SOURCES}

Communication from the Commission to the European parliament, the Council, the European Economic and Social Committee and the Committee of the Regions (2020): A Union of Equality: Gender Equality Strategy 2020-2025. COM/2020/152 final. Accessible at https://eur-lex.europa.eu/legal-content/EN/ TXT/?uri=CELEX:52020DC0152, 10. 1. 2021.

Covid-19 Tracker (2020): Measures and Restrictions. Accessible at https://covid-19. sledilnik.org/en/restrictions, 10. 1. 2021.

Eurofound (2020a): Women and Labour Market Equality: Has Covid-19 Rolled Back Recent Gains? Luxembourg: Publications Office of the European Union. Accessible at https://www.eurofound.europa.eu/publications/policy-brief /2020/women-and-labour-market-equality-has-covid-19-rolled-back-recentgains, 10. 1. 2021. 
Eurofound (2020b): Living, Working and Covid-19. Covid-19 series. Luxembourg: Publications Office of the European Union. Accessible at https://www.eurofound.europa.eu/sites/default/files/ef_publication/field_ef_document/ef20059 en.pdf, 10. 1. 2021.

Eurofound (2020c): Living, Working and Covid-19 Dataset. June/July 2nd round. Dublin. Accessible at http://eurofound.link/covid19data, 10. 1. 2021.

Eurostat (2020a): Employment in Detail - Quarterly Statistics. Accessible at https:// ec.europa.eu/eurostat/statistics-explained/index.php?title=Employment_in_ detail_-_quarterly_statistics (10.1.2021).

Eurostat (2020b): Absences from Work - Quarterly Statistics. Accessible at https:// ec.europa.eu/eurostat/statistics-explained/pdfscache/88646.pdf, 10. 1. 2021.

Eurostat (2020c): Flexibility at Work - Statistics. Accessible at https://ec.europa.eu/ eurostat/statistics-explained/index.php?title=Flexibility_at_work_-_statistics, 10. 1. 2021.

Eurostat (2021a): Online data browser. Accessible at https://ec.europa.eu/eurostat/ data/database, 10. 1. 2021.

Eurostat (2021b): Weekly Absences from Work. Accessible at https://ec.europa.eu/ eurostat/statistics-explained/pdfscache/89236.pdf, 25. 1. 2021.

Gospodarska zbornica Slovenije (2020): Covid-19: Uporabne informacije in povezave. Accessible at https://www.gzs.si/zbornica_komunalnega_gospodarstva/ vsebina/Covid-19/Uporabne-povezave, 10. 1. 2021.

ILO (2020): Teleworking During the Covid-19 Pandemic and Beyond: A Practical Guide. Geneva: International Labour Office, July 2020. Accessible at https:// www.ilo.org/wcmsp5/groups/public/---ed_protect/---protrav/---travail/documents/instructionalmaterial/wcms_751232.pdf, 10.1. 2021.

ILO (2021): Covid-19 and the World of Work: Country Policy Responses. Accessible at https://www.ilo.org/global/topics/coronavirus/regional-country/countryresponses/, 10. 1. 2021.

Rutar, Katja and Marko Tomažič (2020): Metodološko pojasnilo: Aktivno in neaktivno prebivalstvo. Ljubljana: Statistični urad. Accessible at https://www.stat.si/ statweb/File/DocSysFile/7788, 10. 1. 2021.

Slovenske novice (14. 12. 2020): ANDRAŽ: RUTINA, KI UBIJA. Minister s to objavo razburil veliko družin, napako je zdaj priznal. Accessible at https://www.slovenskenovice.si/novice/slovenija/minister-s-to-objavo-razburil-veliko-druzinnapako-je-zdaj-priznal/, 10. 1. 2021.

Statistical Office (2021): SiStat Database. Accessible at https://pxweb.stat.si/SiStat/ en, 10. 1. 2021.

Zalaznik, Janez (22. 10. 2020): Toliko uslužbencev po ministrstvih dela od doma. Žurnal24.SI. Accessible at https://www.zurnal24.si/slovenija/toliko-usluzbencev -po-ministrstvih-dela-od-doma-355320, 10. 1. 2021.

Zavod RS za zaposlovanje (2020): Obvestilo za javnost: DECEMBER 2020. Accessible at https://www.ess.gov.si/_files/13786/Trg_dela_december_2020.pdf, 10. 1. 2021. 